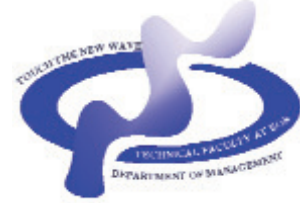

Serbian Journal of Management 13 (1) (2018) 47 - 62
Serbian

Journal of

Management

www.sjm06.com

\title{
ECONOMIC ANALYSIS OF THE PROJECT OF WAREHOUSE CENRTALIZATION IN THE PAPER PRODUCTION COMPANY
}

\author{
Željko Stevića $^{\text {* }}$, Enis Mulalićb ${ }^{\text {, Zdravko Božičkovića }}{ }^{\text {, }}$ \\ Slavko Veskovićc and Irena Đalića

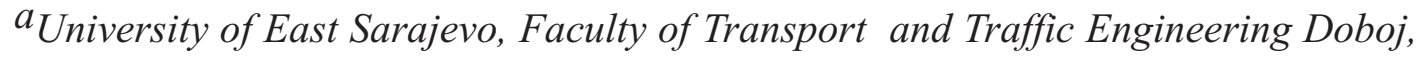 \\ Vojvode Mišića 52, 74000 Doboj, Bosnia and Herzegovina \\ $b_{\text {Natron-Hayat d.o.o. Liješnica bb Maglaj, Bosnia and Herzegovina }}$ \\ ${ }^{c}$ University of Belgrade, Faculty of Transport and Traffic Engineering, \\ Vojvode Stepe 305 Belgrade, Serbia
}

(Received 04 March 2017 ; accepted 19 July 2017)

\begin{abstract}
In the modern conditions, business requires constant rationalization of all activities and processes that occur in the logistics system. One of the preconditions for ensuring the competitiveness in the market is to manage the own performance. This paper presents research that relates to the project of centralization of the warehouse in the company of paper production. Currently, any production facility has its own warehouse that is, through executed decomposition, proved like a poor solution. Any project requires certain investment funds, which are in this case over half million EUR, because it is a large and complex logistics company that employs about one thousand workers. The focus of this paper is an economic analysis of the project of centralization of warehouse. The new centralized system gives better results in the comparison with the current system of decentralization. Considering the savings, which are realized by switching to a centralized warehouse system, and required investment funds, repayment period of the same is slightly less than five years, what is relatively a short period.
\end{abstract}

Keywords: Economic analysis, warehouse, transport, costs

\section{INTRODUCTION}

Today, according to (Gunasekaran \& Ngai, 2004), in the 21st century, the management of supply chain is a global strategy how to achieve a competitive advantage, where, according to (Grabara et al., 2014), the most important logistics activity is transport, and according to (Ballis, 2006) the warehouse is a basic element in complexes such as different forms of logistics centers and their efficient planning and operating are essential for the efficient operation of the entire supply chain. From

\footnotetext{
* Corresponding author: zeljkostevic88@yahoo.com
}

DOI: $10.5937 /$ sjm13-13608 
the above mentioned it can be concluded how much the transport and storage are important in a complete logistics system, which is also proved by the fact that, despite the different authors and different attitudes that prevailing in the field of logistics, transport and storage are the basic subsystems in all divisions. According to (De Koster, 1998) it is necessary to appropriately manage the processes within the warehouse system so that the company could increase its competitiveness. More details about claims and benefits that effective storage processes ensure are in (Gunasekaran et al., 1999; Petersen, 1999).

In this research, it has been made decomposition of warehouse and internal transport system in order to determine the critical places of business in the logistics system.

After that, it has been made a project of transition from a decentralized to a centralized storage system which can greatly contribute to the realization of certain savings, what is highlighted by this paper. To complete this project, in this paper it were clearly defined investment costs of switching to a centralized storage system, and it was carried out economic feasibility of entering into investments, with a display of current costs and possibilities of their reduction through the implementation of this project.

\section{RESEARCH}

Natron Hayat company is an integrated factory for the production of brown kraft paper produced from the pulp and coniferous timber, packaging paper based on waste paper that has been used for the manufacture of corrugated cardboard and boxes, then for processing paper in paper bags, shopping bags with and without handles, formatted paper, paper coated with polyethylene and other similar products. The paper from Natron Hayat company is exported to over 40 countries worldwide.

\subsection{Production facilities of company}

The production in the company is realized through a number of technological processes. The production processes represent a dynamic system, and there is movement of materials (material flows) and the movement of information (information flows).

The most important production facilities within the company are three existing paper machines $\left(\mathrm{PM}_{4}\right.$ Paper machine, $\mathrm{PM}_{1}$ Paper machine, $\mathrm{PM}_{3}$ Paper machine) as well as production facilities Confection \& Cardboard. It is important to emphasize that in addition to the above production facilities, additional investments are planned in order to cover the current demand of Natron paper on the world market. In this paper, more attention will be given to the planning and analysis of commodity flows, and more precisely to the internal transport system as well as the storage of finished products.

The specified facilities within the company are distributed evenly and according to the plan. Paper machine $\mathrm{PM}_{1}$, Paper machine $\mathrm{PM}_{3}$, Confection facilities, as well as future investment - Paper machine $\mathrm{PM}_{6}$, are located in a common facility with precisely divided units and with a separate system of storage of finished products. Paper machine $\mathrm{PM}_{4}$, as one of the most important production facilities within the company, represents a separate entity with special separate facilities and with a separate system 
of the storage of finished products. The entire production process is carried out in certain production facilities within the company. In this paper, the focus will be on the most important production machines, which are:

- Paper Machine $\mathrm{PM}_{4}$ - is producing packaging paper made of pure cellulose wood, more precisely from fibers of pine, spruce and fir, what gives additional strength and quality to paper. The installed equipment in facilities is purchased from leading manufacturers. The most important products of paper machine $\mathrm{PM}_{4}$ are CLUPAKextensible paper, kraft Standard.

- Paper machine $\mathrm{PM}_{3}$ - is producing MG paper, made from pure cellulose. This paper is most commonly used in the production of paper packaging, small paper bags for vegetables, baked goods and shopping bags.

- Paper machine $\mathrm{PM}_{1}$ - is producing

Schrenz, Fluting, Teslainer paper used for making cardboard and cardboard packaging. This kind of paper is vital in creation of strong board/boxes, because of its characteristics it has influence on the strength and quality of the cardboard.

Confection production facility - is producing different sizes and shapes of sacks and bags with or without print. As a raw material, in most cases, they use their own paper from production facilities of the company.

The future investment of company is also considered, and it is the $\mathrm{PM}_{6}$ paper machine with all its accompanying parameters of production and assumptions about the way of the storage of finished products of mentioned machines.

\subsection{Warehouses within the company}

As parts of the production process, which are treated in this paper, the company has four warehouses that serve for storage of finished products of four production machines. These warehouses are:

- Warehouse of Paper machine $\mathrm{PM}_{4}$ (Kraft paper, Clupak),

- Warehouse of Paper machine $\mathrm{PM}_{1}$ $\mathrm{PM}_{3}$ (Schrenz, Fluting, Teslainer),

- Warehouse of Confection Production facility (sacks and bags),

- Customs warehouse.

Stock management takes place using the ABC analysis, which is explained in detail in (Vollmann et al., 1997; Stock \& Lambert, 2001; Teunter et al., 2010). One of the most important items of warehouse is a stock management system, which according to

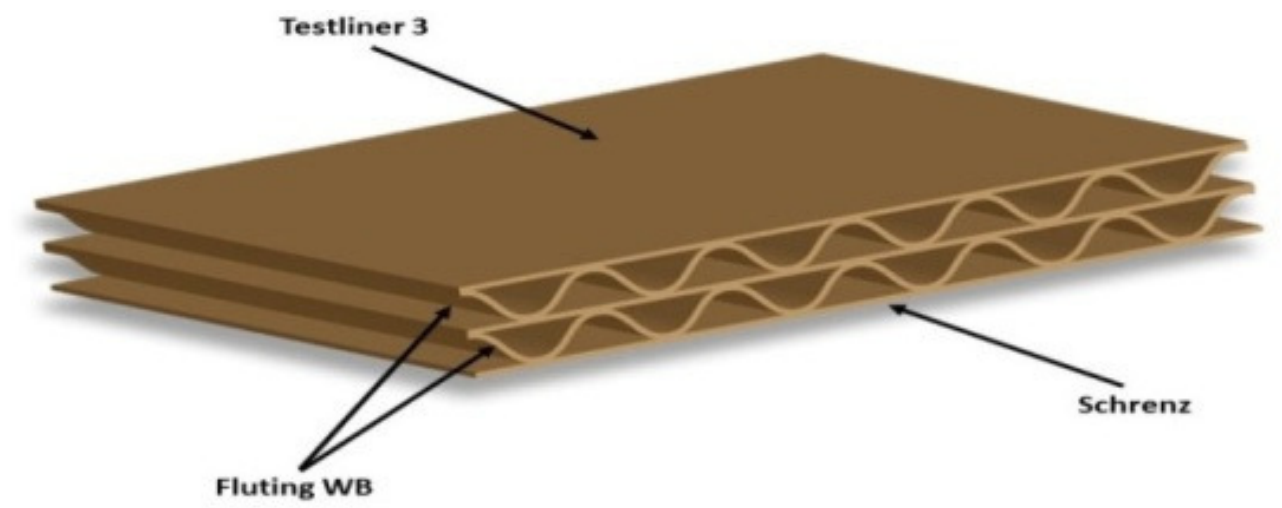

Figure 1. Parts of the cardboard 
(Gattorna \& Walters, 1996), is up to $30 \%$ of total logistics costs. For this reason it is not a rare situation that the terms, warehouse and stock, are closely related in the literature (McGinnis \& Kohn, 1998; Baker, 2007).

\subsection{Centralization of storage system}

There are two basic strategies in stock and warehouse management: centralized and decentralized (Faccio, 2015). The centralized storage is better way of stock control, and according to (Das \& Tyagi, 1997; Croxton \& Zinn, 2005) it reduces costs and total inventories. The research on effects of centralized systems is not rare case and it is executed by many companies, as an example (Johansson \& Peters 2014; Lämsä \& Mattsson, 2014).

The facility that this work provides for the formation of the central warehouse is an old Pulp facility. This facility is located within the company and it is not currently in use because of the termination of the same and construction of a new, more modern facility. This facility contains a large covered area and provides a possibility of forming a central warehouse. In addition, on a distance of $50 \mathrm{~m}$ there is a custom warehouse which is already in use and which performs storage of certain products. The location of the future central warehouse facility provides an opportunity for storage and dispatch of finished goods by road and rail.

\section{ECONOMIC ANALYSIS OF CENTRALIZATION OF WAREHOUSE}

That this project will be economically viable, it is necessary to compare the investment of centralized warehouse, operating costs and revenues. This paper will show certain deficiencies and suggest some activities regarding internal transport and storage, which can be carried out to achieve some savings in order to attain the economic viability of the entire project. Besides, the aim is to provide better organization of work in these areas which would result in better and faster goods flow.

\subsection{The cost of reconstruction of the facility and putting it into operation as a warehouse}

The biggest cost of the facility would be the cost of reconstruction of the roof installations. After the reconstruction of the roof installations it is necessary to clean the floor, what includes the demolition of concrete structures and the removal of unnecessary walls. Also, it is necessary to break and to set up fronts from the south and north sides of the building for loading road and rail vehicles. Since the building is composed of three levels, more precisely, of the ground floor, first floor and second floor, it is necessary to install a lift, of the capacity of $2 \mathrm{t}$, for the vertical mode of goods transport.

The current floor of the facility does not meet the standards of storage and it is necessary to use a special floor "ferroconcrete". This type of floor exclusively meets the standards of all types of closed warehouses. Currently, the facility has no electricity so it is essential to include an item concerning the electrical installations as well as setting the lighting devices prescribed by standards. In addition to the installation of electricity there are also costs of repairing sewer and water installation. Within the facility it is necessary to equip ancillary rooms. In the central warehouse it has been planned to reconstruct existing 
Table 1. Display of costs for the reconstruction of the central warehouse

\begin{tabular}{|c|c|c|c|c|c|c|}
\hline $\begin{array}{l}\text { Order } \\
\text { No. }\end{array}$ & Name & $\begin{array}{l}\text { Unit of } \\
\text { meas. }\end{array}$ & $\begin{array}{c}\text { Individual } \\
\text { price }\end{array}$ & Quan. & Price & Currency \\
\hline 1 & $\begin{array}{l}\text { Cutting and removal of concrete } \\
\text { foundation supporting structures }\end{array}$ & $\mathrm{m}^{3}$ & 127.825 & 60 & 7669.50 & EUR \\
\hline 2 & $\begin{array}{l}\text { Removing concrete kabe, holender, } \\
\text { and their removal to landfill }\end{array}$ & $\mathrm{m}^{3}$ & 173.842 & 240 & 41722.08 & EUR \\
\hline 3 & $\begin{array}{l}\text { Upgrading the plates on the first } \\
\text { and second floor }\end{array}$ & $\mathrm{m}^{3}$ & 51.13 & 780 & 39881.40 & EUR \\
\hline 4 & $\begin{array}{l}\text { Clearing and rehabilitation of the } \\
\text { floor with the installation of } \\
\text { "ferroconcrete" }\end{array}$ & $\mathrm{m}^{2}$ & 34.77 & 4043 & 140575.1 & EUR \\
\hline 5 & $\begin{array}{l}\text { Rehabilitation of the roof } \\
\text { installation }\end{array}$ & $\mathrm{m}^{2}$ & 51.13 & 5500 & 281215 & EUR \\
\hline 6 & Installing the doors & pieces & $* * * * * *$ & 8 & 2045 & EUR \\
\hline 7 & Installing the lift, the capacity of $2 \mathrm{t}$ & pieces & 15339 & 1 & 15339 & EUR \\
\hline 8 & Installation of reloading fronts & pieces & 10226 & 3 & 30678 & EUR \\
\hline 9 & Installing the lighting LED 50W & pieces & 25.56 & 20 & 511.2 & EUR \\
\hline 10 & Laminate & $\mathrm{m}^{2}$ & 7 & 280 & 1960 & EUR \\
\hline 11 & A toilet & pieces & 2556.5 & 3 & 7669.5 & EUR \\
\hline 12 & Installing the tarpaulin hall & $\mathrm{m}$ & 127.825 & 150 & 19173.75 & EUR \\
\hline \multirow[t]{2}{*}{13} & The cost of buying a wagon & pieces & 9970.35 & 2 & 19940.7 & EUR \\
\hline & & & & & 581537 & EUR \\
\hline
\end{tabular}

ancillary rooms and set up: a room for warehouse workers, office for managers of warehouse, offices for shipping agents and biller, medical room, space for forklifts and other. Also, it is recommended to install a fire alarm system that will fulfill security conditions of the warehouse.

Table 1 shows the costs describing the basic investments for the rehabilitation and putting into operation the planned facility for the purpose of the central warehouse. In Table 1 it can be seen that it is necessary to allocate EUR 581537 for a rough repair of facility and its preparation for storage of finished products. According to information of experts, the degree of tolerance in the budget moves by $20 \%$ of the total amount of costs what is defined by standards in the construction industry. In the compilation of Table, directly or indirectly, experts from companies which have some experience in these areas have been involved. Some of the persons are from the building maintenance, procurement sector, electrical maintenance, finance sector as well as other organizational units in the company.

According to advice from the working unit of building maintenance, all activities with the aim to remove old concrete installation of machinery must be performed exclusively by cutting the concrete structures. It is not recommended to use pneumatic means because of the high friction that these machines cause, and because of the danger of possible collapsing during the operations.

Since the warehouse of paper machine $\mathrm{PM}_{1}-\mathrm{PM}_{3}$ and the warehouse of Confection production facility are located along the railroad tracks, it is necessary to make a connection between the wagon and the warehouse. The same case applies to the central warehouse. The distance from the ramp of the mentioned objects and railways is about $1 \mathrm{~m}$. 
3.2. Current costs of the storage and transport

Logistics costs, according to (Radivojevic et. al., 2007), include the costs of all processes and activities related to material flows and services from the place of origin to the final consumer.

These costs can be divided into two groups, fixed costs and variable costs. Some of these costs are: costs of internal transport, costs of storage of products, the cost of stock, the cost of all activities of transfer, cost of preparation of goods and accompanying documents, the cost of mediation, freight forwarding and agency services, and others.

\subsubsection{Fixed costs}

Fixed costs are the costs of salaries, hot meals and other contributions of all employees in the warehouse of paper machine $\mathrm{PM}_{4}$, in the warehouse of paper machine $\mathrm{PM}_{1}-\mathrm{PM}_{3}$ and in the warehouse of Confection production facility and billers. 10 employees, who are supposed to participate in the work of the future warehouse of paper machine $\mathrm{PM}_{6}$, will be added to this cost.

The total number of employees (support workers, forklift drivers, billers, Registrars and the main workers in warehouse together with the possible number of employees in the warehouse of paper machine $\mathrm{PM}_{6}$ ) is approximately 51 workers.

In Table 2, there are presented the fixed costs for 51 employees. From the Table it can be concluded that, for January-July 2016, the company allocates costs in the amount of about EUR 243888.48.

\subsubsection{Variable costs}

The variable costs include the costs of: forklifts and other transport-transfer means, the office supplies, hygiene, electricity, heating, etc. Some of the costs of forklift and other transport-transfer means are: the cost of fuel, oils, lubricants, spare parts, services of third parties and others. It should be noted that the variable costs are changing in the amount which is proportional to the change in production volume.

These costs are increasing or decreasing in proportion (in the same proportion to the increase or decrease of capacity utilization). Further in the paper, there will be all statistical parameters of transport-transfer means which are used for work in the warehouse of paper machine $\mathrm{PM}_{4}$, paper machine $\mathrm{PM}_{1}-\mathrm{PM}_{3}$ and warehouse of Confection production facility as well as in

Table 2. Display of the fixed costs for the period January-July 2016

\begin{tabular}{lcllccc}
\hline \multicolumn{1}{c}{$\begin{array}{c}\text { Average salary } \\
\text { EUR 494.580 }\end{array}$} & \multicolumn{5}{c}{ The total number of employees in the delivery of products } \\
\hline Hot meal & & 123.02 & EUR & 51 & 43919.211 & EUR \\
Transportation of employees & & 19.26 & EUR & 51 & 6875.106 & EUR \\
$\begin{array}{l}\text { Average salary - total } \\
\text { Hot meal - total }\end{array}$ & 176565.06 & EUR & & & \\
$\begin{array}{l}\text { Transportation of employees } \\
- \text { total }\end{array}$ & 63919.211 & EUR & & & \\
$\begin{array}{l}\text { Total staff costs } \\
\text { Other fixed costs }\end{array}$ & 227359.106 & EUR & & & \\
Total fixed costs & 243888.48 & EUR & & & \\
\hline
\end{tabular}


the conduct of internal transport.

Transport vehicles that perform this function are: five forklifts, Mercedes Benz truck, truck with trailer, loco tractor.

Table 3 shows statistic data that describe the number of working hours of forklifts (Linde 11 and Linde 12) in the warehouse of paper machine $\mathrm{PM}_{4}$ for the period from January $1^{\text {st }} 2016$ to July $31^{\text {st }} 2016$. In the Table it can be seen that, during this period, the total number of working hours for the two forklifts from this warehouse is $\mathbf{4 2 8 6}$ working hours. If the number of hours will be multiplied by an average of fuel consumption, that is 2.5 liters per working hour, and by EUR 0.767, that is the average cost of diesel fuel, the obtained result is EUR 8217.87. To this amount of fuel consumption it also must be added consumption of the loco tractor with a trailer that transports bobbins from the warehouse to the customs warehouse. The largest transport cycle is carried from the warehouse of paper machine $\mathrm{PM}_{4}$, but also the tractor serves to transport the products from the warehouse of paper machine $\mathrm{PM}_{3}-\mathrm{PM}_{1}$ in the customs warehouse.

The total number of working hours is 928 for the period that was taken for the calculation. If this amount will be multiplied by 3 liters (consumption per a working hour), the obtained result is 27841 and if that amount will be multiplied by EUR 0.767 (average purchase price of diesel fuel) the obtained result is EUR 2135.19.

From these two calculations it can be seen that the warehouse of paper machine $\mathrm{PM}_{4}$ spends EUR 10353.06 per item of fuel consumption for 7 months.

As for the warehouse of paper machine $\mathrm{PM}_{3}-\mathrm{PM}_{1}$, in addition to storage activity, transport-reloading means in this warehouse also serve other production facilities in the company (Finishing, Cardboard, Confection). For such activities, besides the two forklifts, the aforementioned truck is also used.

Table 4 shows separated numbers of working hours of forklifts and their total consumption for the period from January $1^{\text {st }}$ 2016 to July $31^{\text {st }} 2016$.

According to data in the Table 4 it can be seen that the total number of working hours of forklifts for the above mentioned period is 1950.9 , and multiplying this amount by the average consumption per working hours of the forklift (2.5 liters per hour), the obtained amount is 4877.251 . Multiplying that amount by the average cost of fuel of 0.767 EUR/liter per annum, the obtained a score is

Table 3. Overview of forklifts in the warehouse of the $P_{4}$ paper machine

\begin{tabular}{clccc}
\hline $\begin{array}{c}\text { Order } \\
\text { No. }\end{array}$ & \multirow{2}{*}{ Month } & \multicolumn{2}{c}{ Forklift } & \multirow{2}{*}{ Total } \\
\hline 1 & January & $366 \mathrm{wh}$ & $388 \mathrm{wh}$ & $754 \mathrm{wh}$ \\
2 & February & $396 \mathrm{wh}$ & $365 \mathrm{wh}$ & $761 \mathrm{wh}$ \\
3 & Mach & $199 \mathrm{wh}$ & $201 \mathrm{wh}$ & $400 \mathrm{wh}$ \\
4 & April & $295 \mathrm{wh}$ & $302 \mathrm{wh}$ & $597 \mathrm{wh}$ \\
5 & May & $354 \mathrm{wh}$ & $332 \mathrm{wh}$ & $686 \mathrm{wh}$ \\
6 & June & $348 \mathrm{wh}$ & $239 \mathrm{wh}$ & $587 \mathrm{wh}$ \\
7 & July & $202 \mathrm{wh}$ & $299 \mathrm{wh}$ & $501 \mathrm{wh}$ \\
Total & & & & $4286 \mathrm{wh}$ \\
\hline
\end{tabular}


Table 4. Overview of forklifts in the warehouse of $P M_{3}-P M_{1}$

\begin{tabular}{|c|c|c|c|c|}
\hline \multirow{2}{*}{$\begin{array}{c}\text { Order } \\
\text { No. }\end{array}$} & \multirow{2}{*}{ Month } & \multicolumn{2}{|c|}{ Forklift } & \multirow{2}{*}{ Total } \\
\hline & & LINDE 10 & LINDE 9 & \\
\hline 1 & January & $199.6 \mathrm{wh}$ & $122.3 \mathrm{wh}$ & $321.9 \mathrm{wh}$ \\
\hline 2 & February & $223.8 \mathrm{wh}$ & $146.2 \mathrm{wh}$ & 370 wh \\
\hline 3 & Mach & 76 wh & $32.9 \mathrm{wh}$ & $108.9 \mathrm{wh}$ \\
\hline 4 & April & $201 \mathrm{wh}$ & $56.1 \mathrm{wh}$ & $257.1 \mathrm{wh}$ \\
\hline 5 & May & $235 \mathrm{wh}$ & $102 \mathrm{wh}$ & 337 wh \\
\hline 6 & June & $230 \mathrm{wh}$ & $32 \mathrm{wh}$ & $262 \mathrm{wh}$ \\
\hline 7 & July & 205 wh & 89 wh & $294 \mathrm{wh}$ \\
\hline Total & & & & $1950.9 \mathrm{wh}$ \\
\hline
\end{tabular}

EUR 3740.86.

1950.9 w.h x 2.5 l/w.h=4877.25 1

$4877.250 .767 \mathrm{EUR} / \mathrm{l}=$ EUR 3740.86

According to the research and the data which are obtained for seven months, Mercedes Benz truck spends 1360 liters. If that amount will be multiplied by the average cost of fuel of $0.767 \mathrm{EUR} /$ liter per annum the obtained result is EUR 1043.12.

$13601 \times 0.767 \mathrm{EUR} / 1=$ EUR 1043.12

From these two calculations it can be seen that the warehouse of paper machine $\mathrm{PM}_{1^{-}}$ $\mathrm{PM}_{3}$ spends, per item of fuel consumption, EUR 3740.86 + EUR 1043.12 = EUR 4783.98 for 7 months.

Item 3, in Table 5, describes gas consumption while the remaining items are the consumption of diesel fuel.

Table 6 shows the total consumption of fuel and gas of the conveying-transport means in the three above mentioned warehouses, respectively there are represented variable costs of all three warehouses in the period from January $1^{\text {st }}$ to July $31^{\text {st }} 2016$. From the Table it can be seen that the total variable costs are EUR 23894.6. However, these costs will be increased with the opening of the warehouse of paper machine $\mathrm{PM}_{6}$.

\subsection{Reduction of costs of Mercedes Benz truck}

Based on the observation, it has been noted that some of savings can be realized by the reduction of the movement of Mercedes Benz truck which is property of the warehouse $\mathrm{PM}_{1}-\mathrm{PM}_{3}$. All activities of the truck can be done through rail transport, more precisely, using loco tractors. This truck carries out the internal transport, more precisely, it supplies other production facilities with inventory from the warehouse.

This type of supply is provided by the truck and forklift. The cycle of movement of

Table 5. Movement and consumption of transport and reloading vehicles for 01.01-31.07.2016.

\begin{tabular}{clclll}
\hline $\begin{array}{c}\text { Order } \\
\text { No. }\end{array}$ & Vehicle name & Quan. & Position & $\begin{array}{l}\text { Unit of } \\
\text { measurement }\end{array}$ & Consumption \\
\hline 1 & Forklift & 2 & warehouse $\mathrm{PM}_{4}$ & 4286 w.h & 107151 \\
2 & Forklift & 2 & warehouse $\mathrm{PM}_{3}-\mathrm{PM}_{1}$ & 1950.9 w.h & 4877.251 \\
3 & Forklift & 1 & Confection production facility & $* * * * * * *$ & $2220 \mathrm{~kg}$ \\
4 & Tow tractor with a & 1 & & 928 w.h & 27841 \\
5 & trailer, & 1 & warehouse $\mathrm{PM}_{3}-\mathrm{PM}_{1}$ & $* * * * * * *$ & 13601 \\
\hline
\end{tabular}


vehicles in this process looks like: receipt of order, preparation of order, loading and storage of products, movement of trucks and forklifts up to the processing facility, cardboard facility, unloading of trucks, handover of products in the warehouse of processing facility, cardboard facility, storage of products, return to the warehouse of paper machine $\mathrm{PM}_{3}-\mathrm{PM}_{1}$.

Table 6. Display of variable costs for January-July 2016

\begin{tabular}{llll}
\hline \multicolumn{4}{c}{ Total variable costs } \\
\hline 1 & Diesel & 15136.717 & EUR \\
2 & Propane butane 10 kg & 1532.366 & EUR \\
3 & Oil and lubricants & 1218.837 & EUR \\
4 & Spare parts & 587.58 & EUR \\
5 & Office Supplies & 1022.6 & EUR \\
6 & Third Party Services & 2095.65 & EUR \\
7 & Other consumables & 2300.85 & EUR \\
& & 23894.6 & EUR \\
\hline
\end{tabular}

In addition to the aforementioned activities, the Mercedes Benz truck transfers finished products from the paper machine $\mathrm{PM}_{3}$ to the warehouse of paper machine $\mathrm{PM}_{3}-\mathrm{PM}_{1}$.

It is important to mention that the distance between the warehouses of paper machine $\mathrm{PM}_{3}-\mathrm{PM}_{1}$ and Cardboard facility is about $2 \mathrm{~km}$, from the warehouse of paper machine $\mathrm{PM}_{3}-\mathrm{PM}_{1}$ to Processing facility is about
$1.5 \mathrm{~km}$ and from the paper machine $\mathrm{PM}_{3}$ to the warehouse of paper machine $\mathrm{PM}_{3}-\mathrm{PM}_{1}$ is $500 \mathrm{~m}$.

Based on Table 7, it will show the cycles of movement of this vehicle and the traveled distance in 24 hours.

From the Table it can be concluded that a vehicle crosses over about $48 \mathrm{~km}$ average in one day, with full capacity of all of those production facilities. In the Table it is described a situation when the production facility: Cardboard, Finishing and Paper machine $\mathrm{PM}_{3}$ work with full capacity, and it is necessary for this vehicle to perform its activity all day. However, there are situations when these facilities do not work because of the number of received orders, and then the Mercedes Benz truck does not perform any activity at these machines.

As a part of this research, there is received the data that the consumption of this truck is 22 liters per $100 \mathrm{~km}$ and because it is old, it causes high costs, such as: high consumption of fuels, oils, lubricants, spare parts and which, sometimes, also include services of third parties. Besides, these costs include the annual registration of the vehicle.

The reduction of movement or ejection from the use of these vehicles would lead to significant savings that could be used in any new investment in the company.

Table 7. Display of the Mercedes Benz truck movements on a daily basis

\begin{tabular}{|c|c|c|c|c|c|}
\hline $\begin{array}{l}\text { Order } \\
\text { No. }\end{array}$ & The cycle of movement & $\begin{array}{l}\text { Time } \\
\text { period }\end{array}$ & $\begin{array}{l}\text { Number of } \\
\text { service }\end{array}$ & Mileage & Total \\
\hline 1 & $\begin{array}{l}\text { Providing the service to the } \\
\text { Confection production } \\
\text { facility }\end{array}$ & daily & 20 & $2 \mathrm{~km}$ & $40 \mathrm{~km}$ \\
\hline 2 & $\begin{array}{l}\text { Providing the service to the } \\
\text { Finishing facility }\end{array}$ & daily & 2 & $1.5 \mathrm{~km}$ & $3 \mathrm{~km}$ \\
\hline $\begin{array}{c}3 \\
\text { total }\end{array}$ & Storage of products $\mathrm{PM}_{3}$ & daily & 10 & $0.5 \mathrm{~km}$ & $\begin{array}{r}5 \mathrm{~km} \\
48 \mathrm{~km}\end{array}$ \\
\hline
\end{tabular}


3.4. Reduction of forklift's transfer activity

Another weak point is the excessive movement of the forklift during storage and loading. Some examples where forklifts perform ineffective cycles of movement should be mentioned.

In a situation when the capacity of warehouse is overcrowded, finding a suitable bobbin requires unnecessary movement of unloaded forklifts from one loading place to the other loading place and back to the warehouse. In such a situation, the forklift is moving up to $1 \mathrm{~km}$ to perform a full load of one truck.

When the warehouse is full during the loading of truck, it is necessary to reshuffle a certain number of bobbins in order to reach the appropriate bobbins. When the bobbins are reached it is necessary to put other bobbins in the original position.

During the relocation of bobbins in a customs warehouse it is necessary to engage a truck and a tractor with trailer. The distance by road between the warehouse of paper machine $\mathrm{PM}_{4}$ and customs warehouse is about $1.5 \mathrm{~km}$, and between the warehouse of paper machine $\mathrm{PM}_{1}-\mathrm{PM}_{3}$ is about $2 \mathrm{~km}$. The movement cycle of vehicles in this process looks like:

- the preparation of products for unloading,

- loading products from the warehouse to a tractor with a trailer or to a truck,

- the movement of the tractor with trailer/truck and forklifts to the customs warehouse,

- unloading and storage of products in a customs warehouse,

- $\quad$ the return of transport-transfer means back to the origin warehouse.
For supplying the production facilities with products from the warehouses it is necessary to engage a towing tractor with a trailer or truck together with a forklift. It has already been mentioned that the warehouse of paper machine $\mathrm{PM}_{3}-\mathrm{PM}_{1}$ performs the supply of paper from its stock to the Cardboard and Finishing production facilities. The distance between the warehouse of paper machine $\mathrm{PM}_{3}-\mathrm{PM}_{1}$ and Cardboard facility is $2 \mathrm{~km}$, and between the warehouse of paper machine $\mathrm{PM}_{3}-\mathrm{PM}_{1}$ and Finishing facility is about $1 \mathrm{~km}$. Also, the warehouse of paper machine $\mathrm{PM}_{4}$ provides the supply for the Confection production facility, and the distance between these two facilities is about $1 \mathrm{~km}$.

To move products from the paper machine $\mathrm{PM}_{3}$ to the warehouse of paper machine $\mathrm{PM}_{3}-\mathrm{PM}_{1}$ it is necessary to engage a truck and forklift. Since the paper machine $\mathrm{PM}_{3}$ has no permanent connection with the warehouse of paper machine $\mathrm{PM}_{3}-\mathrm{PM}_{1}$ it is necessary to perform the transfer of finished products of mentioned machines to the appropriate warehouse. The distance between the paper machine $\mathrm{PM}_{3}$ and warehouse is about $0.5 \mathrm{~km}$.

By establishing the central warehouse, these processes would be significantly reduced or eliminated, since all that transport would be performed by loco tractor. During the transport of finished products, a forklift could be transported by loco tractor in one of the wagons. The forklift would carry out transshipment activities in this process. 


\subsection{Greater use of rail transport in internal transport}

In order to describe this view it will be made a comparison between the work of loco tractor, Mercedes Benz truck and towing tractor with trailer. The consumption of loco tractor for 1 working hour is 3.3 liters of diesel fuel. If the loco tractor was more in use in internal transport and if the movement of Mercedes Benz truck (made in 1985) and towing tractor was reduced, there would be obtained huge savings in fuel consumption. Considering that the truck, because it is old, consumes 22 liters of fuel per $100 \mathrm{~km}$, the saving would be about 3554 liters or EUR 2453.166 per period of 7 months. The capacity of transport vehicles is also an advantage. The total capacity of loco tractor with three wagons would be about 140t, and the capacity of tractor and truck is about 20t, which provides significant indicators of justification for the use of loco tractor in internal transport. This method of internal transport would lead to savings not only in fuel, but also in: oil, lubricants, spare parts, tires, registration. This would reduce the intensity of movement of road vehicles by main road, which would lead to: the increase of workers' movement safety, infrastructure protection, avoidance of the blockade of entrances in warehouse of paper machines $\mathrm{PM}_{4}$, and by reduction in the use of road vehicles, the environment would be protected.

\subsection{Reduction of the number of damaged bobbins}

In the top part of the paper it is described that the warehouse of paper machine $\mathrm{PM}_{4}$ annually reaches 40 pieces of bobbins which are affected by: receiving, storage, unloading and loading. Any defect of the bobbins occur due to driver's errors such as overloaded storage capacity and lack of space for handling of forklifts, what is, according to (Christopher, 2005), an item that burdens the costs incurred in the storage system. Considering that one bobbin costs about 900.00 euros, depending on the type and weight, that amount is quite large on a monthly and annual level.

40 bobbins x EUR 897.33 = EUR 35893.2

\subsection{Reduction of costs of accompanying premises}

In the decentralized storage mode, each unit has its own office space, toilets, rooms for additional staff. In this storage system there are now three offices within the warehouse and two offices intended for the biller. Each of these offices requires certain costs, such as costs of office material, costs of hygiene products, costs of electrical energy, costs of equipment (air condition, computers, printers), the costs of thermal heating of associated premises. These costs do not include the planned costs of the offices and other ancillary facilities of the warehouse of paper machines $\mathrm{PM}_{6}$.

In the centralized storage mode, it is planned that all these facilities should be grouped. Within the central warehouse there would be dayrooms, such as offices for the main warehouseman with registrars, office for billers, for other warehouse workers (dressing room), toilets and others.

\subsection{Savings in human resources}

As already mentioned in the top part of the paper, in the current storage system of finished products there are 33 employees 
within warehouses and 8 billers. This number of employees does not include the required number of workers who carry out the process of storage and shipment of finished products from the planned paper machine $\mathrm{PM}_{6}$. Assuming that additional 10 workers will be employed in the stock of paper machine $\mathrm{PM}_{6}$, the total number of workers is 51 . The use of central warehouse would lead to a significant reduction of human resources, which would be used to fill the lack in other units.

Taking into account that the logistics sector covers drivers of forklifts in production units, there is a possibility of shedding those jobs with people provided from the savings that will arise from the implementation of this project. Also, during this research, some information has revealed that a certain number of employees in warehouses will fulfill the conditions for retirement in the near future. According to rough estimates, in the system of central warehouse, job schedule would look like:

- $\mathrm{PM}_{4}$ warehouse - 8 workers,

- $\mathrm{PM}_{3}-\mathrm{PM}_{1}$ warehouse - 8 workers,

- Driver of loco tractors - 4,

- Central warehouse - 12,

- Registrars - 4 workers,

- $\quad$ Billers - 4,

- Main warehouseman - 1 worker.
According to the system of central warehouse, it is anticipated that a total number of 41 employees are involved in this process.

Table 2 shows the fixed costs for the period from January to July 2016, which are EUR 243888.48 for 51 employees. Comparing these costs with fixed costs of 41 employees (Table 8), who are considered to participate in the central warehouse, it is EUR 196066.92, and obtained savings are EUR 47821.56 in the period of 7 months.

\subsection{Savings in the transport-reloading} means

The current number of available transport-reloading means is: 5 forklifts, a truck, a towing tractor and a tractor loco. Assuming that another 2 forklifts work in the warehouse of paper machine $\mathrm{PM}_{6}$, there is a number of 7 forklifts, a truck, a towing tractor and a tractor loco.

In the system of the central warehouse there is recommended:

- the central warehouse: 4 forklifts with a driver's seat with the capacity of $2 \mathrm{t}$ ( 3 forklifts which, within the part of the lifting mechanism, have gripper devices in the form of a spoon and 1 forklift that, within the part of the lifting mechanism, has gripper devices in the form of a fork),

Table 8. Fixed costs in the central warehouse

\begin{tabular}{|c|c|c|c|c|}
\hline Average salary & \multicolumn{4}{|c|}{ The total number of employees in the central warehouse } \\
\hline 494.580 EUR & \multicolumn{4}{|c|}{41} \\
\hline Hot meal & 123.02 EUR & 41 & 35306.74 & EUR \\
\hline Transportation of employees & 19.26 EUR & 41 & 5527.62 & EUR \\
\hline Average salary - total & 141944.46 EUR & & & \\
\hline Hot meal - total & 35306.74 EUR & & & \\
\hline Transportation of employees & & & & \\
\hline- total & 5527.62 EUR & & & \\
\hline Total staff costs & 182778.82 EUR & & & \\
\hline Other fixed costs & & 46.3EUR & 41 & 13288.1 \\
\hline Total fixed costs & 196066.92 EUR & & & EUR \\
\hline
\end{tabular}


- $\quad$ the warehouse of paper machine $\mathrm{PM}_{4}$ ( 1 forklift that, within the part of the lifting mechanism, has a gripper device in the form of a spoon),

the warehouse of paper machine $\mathrm{PM}_{3}-\mathrm{PM}_{4}$ (1 forklift that, within the part of the lifting mechanism, has a gripper device in the form of a spoon),

- the internal transport: a loco tractor with 3 closed wagons.

Comparing the current situation with future investments in the warehouse of paper machine $\mathrm{PM}_{6}$, it can be concluded that the performance of all processes in the central warehouse, the following transport-reloading means are not required: the Mercedes Benz truck, the towing tractor with a trailer, one forklift and mobile loading ramps.

From the above it can be seen that the use of central storage provides the rationalization of the movement of following vehicles: the Mercedes Benz truck, towing tractor with a trailer and forklift. In the central warehouse, most of the operations of mentioned transport vehicles could be performed using the loco tractor which fuel consumption is considerably lower. Small comparison of fuel saving is based on Table 9, which shows that the fuel consumption of these two vehicles is 4144 liters of diesel fuel or EUR 3178.241 for a period of 7 months. Also, taking into account that 4 forklifts with diesel engine have an average fuel consumption of 15592.25 liters (7 months), the obtained average consumption per forklift is 3898.1 liters or EUR 3015.698.

Based on these indicators, it can be concluded that it would be saved around EUR 6193.888 by reduction of the movement of these vehicles and using the loco tractor.
In addition to fuel savings, there would be achieved savings on other variable costs, such as: oil and lubricants, tires, registration of vehicles, spare parts, and services from third parties during the repairs.

\section{RESULTS AND DISCUSSION}

An efficient analysis of the storage, according to (Hackman, 2008), is traditionally based on the comparison of measured quantitative values. To calculate the cost-effectiveness of centralized warehouse system, in this research, it was used the budget of the total investment and the differences of the total savings based on the results obtained from the implementation of the planned project, Figure 2. The budget of economic analysis has been made as described above because it is impossible to make a feasibility study that includes an accurate presentation of investments, operating costs and revenues per years that would be achieved by the project. Since it is impossible to allocate realized revenues which the warehouse system and internal transport subsystem achieve out of the total revenue, on the one hand, and it is not practical to use the total revenue that the company obtains, on the other hand, so this mode of budget imposes as the only current solution.

The total investment in the project of centralized warehouse system (Table 1) is EUR 581537, and this investment is intended for the reconstruction and rehabilitation of the facility. The total planned cost savings, which are based on fixed costs as well as on reduced number of damaged bobbins, is EUR 74952.996 in a period of 7 months. According to the calculations, the company would save EUR 10707.571 monthly or 


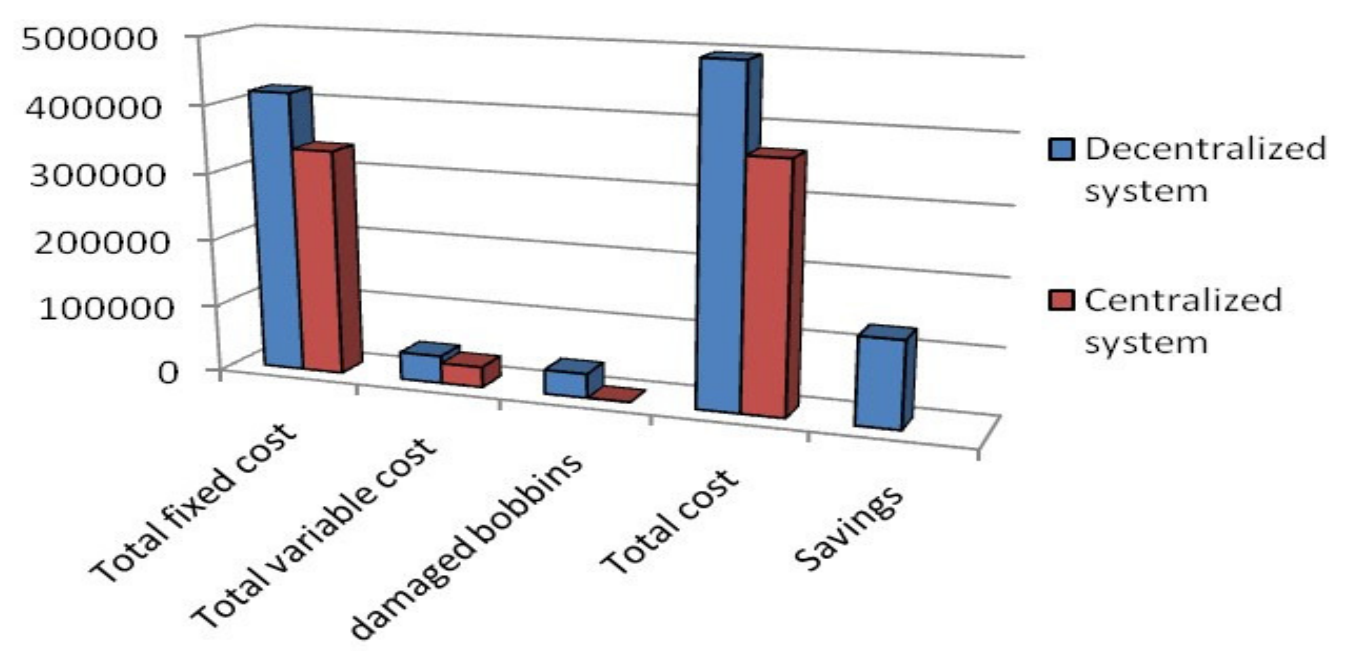

Figure 2. Cost and saving of two systems

EUR 128490.852 annually. It means that the payback period of investment funds in the centralized warehouse system $\approx 57$ months.

\section{CONCLUSION}

Generally, the project of centralization is divided into several stages, and the first stage is decomposition of warehouse and system of internal transport. After that, it has been made a very large and high-quality analysis that shows the shortcomings of the current decentralized storage system, together with the internal transport subsystem, and based on the completed analysis there are given the recommendations for improvement of the entire logistics system. The next stage is a proposal for the centralization of the warehouse system with a detailed description of the implementation of the project and with all activities and resources which are required for smooth operation of logistic activities and processes in it. The last stage is an economic analysis of the proposed project, which shows very promising results. It has been made a detailed analysis of the investments which are required for the centralization of warehouse system and its structure is given in the paper. In order to make any economic analysis, it must be taken into account the operation costs of the centralized warehouse system or savings arising from comparison of two systems.

From all this what is made and also completed budgets which are tabulated in the paper, it can be seen a relatively short payback period of investment funds, which is extremely important, especially because it comes to the millions in investment. The repayment period is less than five years. Taking into account the fact that there are some savings presented in previous chapter, and which are very difficult to quantify and which are not taken into account in the budget, but which are displayed qualitatively, there is a possibility to shorten the period for the repayment of funds.

It is very difficult to give a precise answer to the question which system is better, decentralized or centralized. One of the reasons for this is the fact that these strategies have not been studied too much in production related systems which is 


\title{
ЕКОНОМСКА АНАЛИЗА ПРОЈЕКТА ЦЕНТРАЛИЗАЦИЈЕ СКЛАДИШНОГ СИСТЕМА КОМПАНИЈЕ ЗА ПРОИЗВОДЫУ ПАПИРА
}

\author{
Жељко Стевић, Енис Мулалић, Здравко Божичковић, \\ Славко Весковић и Ирена Ђалић
}

\begin{abstract}
Извод
Пословање компанија у савременим условима захтева константну рационализацију свих активности и процеса који се одвијају у логистичком систему. Један од предуслова за обезбеђење конкурентности на тржишту је управљање сопственим перформансама. У овом раду је извршено истраживање који се односи на пројекат централизације складишног система у компанији за производњу папира. Тренутно свако производно постројење има сопствени складишни простор који се кроз извршену декомпозицију показао као лоше решење. Сваки пројекат захтева одређена инвестициона средства која у овом случају износе преко пола милиона евра, јер ради се о великом логистичком комплексу и компанији која запошлљава око хиљаду радника. Акценат овог рада је на извршеној економској анализи пројекта централизације, која узимајући у обзир поређење тренутног система и планираног новог стања. Упоређење децентрализације складишта и новопројектованог централизованог система даје добре аналитичке резултате. Обзиром на уштеде које се остварују преласком на централизовани систем складиштења и потребним инвестиционим средствима, период повратка истих је нешто мањи од пет година, што предствља релативно кратак период.
\end{abstract}

Кључне речи: економска анализа, складишни систем, транспорт, трошкови

confirmed by (Facio, 2015). According to (Das \& Tyagi, 1997), the decision about which system will be used depends above all on the type of industrial system and the geographic location of the user. In some cases, the costs of a centralized system can be higher than of decentralized one. However, in this specific case, the centralization of warehouse system is justified, especially since the company is not obliged to distribute the goods. In this case, according to (Das \& Tyagi, 1997) the centralization is optimal.

The future research, related to this project of the centralization of warehouse system in the company, refers to the purchase of railway wagons which would allow the performance of internal transport as described in this paper. In addition, during the implementation of the project, it is possible to model the total and required number of transfer fronts by applying queuing systems, and it is constantly possible to carry out the measurement and monitoring of logistics performance in the new storage system, of course, with a special emphasis on the internal transport subsystem.

\section{References}

Baker, P. (2007). An exploratory framework of the role of inventory and warehousing in international supply chains. The International Journal of Logistics Management, 18 (1), 64-80.

Ballis, A. (2006). Freight villages: 
warehouse design and rail link aspects. Transportation Research Record: Journal of the Transportation Research Board, 1966 (1), 27-33.

Christopher, M. (2005), Logistics and Supply Chain Management, London, UK: Prentice Hall.

Croxton, K.L. \& Zinn, W. (2005). Inventory considerations in network design. Journal of Business Logistics, 26 (1), 14968.

Das, C. \& Tyagi, R. (1997). Role of inventory and transportation costs in determining the optimal degree of centralization. Transportation Research: Part E, 33 (3), 171-9.

De Koster, M.B.M. (1998). Recent developments in warehousing. Working Paper, Rotterdam School of Management.

Faccio, M. (2015). Service spare parts versus production parts: a centralised or decentralised warehouse?. International Journal of Logistics Systems and Management, 20(4), 516-535.

Gattorna, J.L. \& Walters, D.W. (1996). Managing the Supply Chain: A Strategic Perspective, London, UK: Macmillan Press.

Grabara, J., Kolcun, M., \& Kot, S. (2014). The role of information systems in transport logistics. International Journal of Education and Research, 2 (2), 1-8.

Gunasekaran, A., \& Ngai, E.W. (2004). Information systems in supply chain integration and management. European Journal of Operational Research, 159 (2), 269-295.

Gunasekaran, A., Marri, H.B. \& Menci, F. (1999). Improving the effectiveness of warehousing operations: a case study. Industrial Management \& Data Systems, 99 (8), 328-339.

Hackman, S.T. (2008). Efficiency Analysis of Warehouse and Distribution
Operations. Production Economics: Integrating the Microeconomic and Engineering Perspectives, 207-220. Chicago, IL: USA, Springer.

Johansson, R., \& Peters, D. (2014). Investigation of the effects of possible centralisations for $\mathrm{ABB}$ sites in the Västerås area, Linköping University.

Lämsä, R., \& Mattsson, S. (2014). Investigation of buying in retail companies Understanding the effects of a central $\begin{array}{llllllllllll} & \mathrm{a} & \mathrm{r} & \mathrm{e} & \mathrm{h} & \mathrm{o} & \mathrm{u} & \mathrm{s} & \mathrm{e} & \text {. }\end{array}$ (http://lup.lub.lu.se/luur/download?func $=$ do wnloadFile\&recordOId=4696019\&fileOId= 4696033)

McGinnis, M.A. and Kohn, J.W. (1998). Warehousing, competitive advantage, and competitive strategy. Journal of Business Logistics, 9 (22), 32-54.

Petersen II, C.G. (1999). The impact of routing and storage policies on warehouse efficiency. International Journal of Operations \& Production Management, 19 (10), 1053-1064.

Radivojević, G. M., Miljuš, M. D., \& Vidović, M. B. (2007). Logistic controlling and performance, Belgrade, Serbia: Faculty of Transportation, University of Belgrade. (In Serbian)

Stock, J.R., \& Lambert, D.M. (2001). Strategic logistics management (4th ed.). Boston, MA, USA: McGraw-Hill/Irwin.

Teunter, R.H., Babai, M.Z., \& Syntetos, A.A. (2010). ABC classification: service levels and inventory costs. Production and Operations Management, 19 (3), 343-352.

Vollmann, T.E. Berry, W.L., \& Whybark, D.C. (1997). Manufacturing planning and control systems (4th ed.), Boston, MA, USA: McGraw-Hill/Irwin. 